УДК 378.147.091.33-022.332(477)

UDC 378.147.091.33-022.332(477)

DOI: $10.31475 /$ ped.dys.2020.29.07

РОМАНА ВОЛКОВЕЦЬКА, магістрант

(Украӥна, Львів, Львівський національний університет ілені Івана Франка, вул. Валова, 18)

ROMANA VOLKOVETSKA,

Postgraduate Student (Ukraine, Lviv, Ivan Franko National University of Lviv, Valova St., 18)

ORCID: 0000-0003-0029-7644

ВАЛЕНТИНА МУДРОХА, кандидат наук з соціальних комунікацій (Україна, Львів, Львівська національна наукова бібліотека ілені Василя Стефбаника, вул. В. Стеббаника, 2)

VALENTYNA MUDROKHA,

Candidate of Sciences in Social Commucation (Ukraine, Lviv, Vasyl Stefanyk National Scientific Library of Ukraine in Lviv, Vasyl Stefanyk St., 2)

ORCID: 0000-0001-9508-227X

ДЕМЧУК НАТАЛІЯ, кандидат фбілологічних наук (Україна, Львів, Львівський національний університет імені Івана Франка, вул. Валова, 18)

NATALIIA DEMCHUK, Candidate of Philological Sciences (Ukraine, Lviv, Ivan Franko National University of Lviv, Valova St., 18)

ORCID: 0000-0003-4236-7794

\title{
Безперервна освіта як домінанта сучасної освітньої парадигми
}

\section{Continuing Education as a Dominant Element of the Modern Educational Paradigm}

Робота присвячена питаннял розвитку систели безперервної освіти як долінанти сучасної освітньої доктрини. Обгрунтовано потребу якнаймасштабніших досліджень явища й становлення окремої спеціальної парадигми $i$ на теоретичному, $i$ на практичному рівнях, зважаючи на поліпрофесіоналізм як характерну ознаку ринку праці, процеси професійної глобалізації, пріоритет інфборлаційних технологій, запровадження як пріоритетного компетентнісного підходу, критично малий період напіврозпаду сучасних компетентностей.

На основі аналізу розрізнених елелентів із досвіду становлення й запровадження безперервної освіти синтезовано основні проблелні питання, вирішення яких забезпечить фбормування иілісної парадигми систели безперервної освіти, а сале: 1)норлування терліносистели безперервної освіти; 2) формування загально-державної освітньої стратегї на рівні принципів, завдань, структури, бборм $і$ методів тощо; 3) забезпечення належного норлативно-правового забезпечення фбункиіонування безперервної освіти як цілісної систели на рівні законів $i$ підзаконних актів; 4) борлування на базі інфраструктури із профбільних інституцій та організацій оптимальної ієрархії закладів освіти, які створюватимуть $i$ надаватилуть освітні продукти ци освітні послуги у ралках безперервної освіти; 5) використання сучасних інформаційних технологій електронного навчання.

Ключові слова: безперервна освіта, післядипломна освіта, освіта для сталого розвитку, освіта впродовж життя, освіта для дорослих, компетентність, терміносистема.

The article deals with the issue of developing the system aiming at continuing education as a dominant element of modern education doctrine. The need for large-scale studies of the phenomenon and the formation of a separate special paradigm at both theoretical and practical levels, taking account of the "multi-professionalism» as a characteristic feature of the labour market, the processes of vocational 
globalization, the priority of information technology, the introduction of outcome-based approach as of the high priority, critically short period of the half-life for modern competences has been substantiated.

Based on the analysis of disparate elements from the experience of the continuing education formation and implementation, the main problematic issues the solution of which will ensure the formation of a holistic paradigm of continuing education have been synthesized, in particular: 1) terminology standardization for the continuing education; 2) establishment of the general state of educational strategy at the level of principles, tasks, structure, forms and methods, etc.; 3) ensuring proper regulatory and legal support for the functioning of continuing education as a holistic system at the level of laws and regulations; 4) formation of the optimal hierarchy of educational institutions, which will create and provide educational products and educational services in the framework of the continuing education by means of the infrastructure of field-oriented institutions and organizations; 5) use of modern information technologies of e-learning.

Key words: continuing education, postgraduate education, education for sustainable development, lifelong education, adult education, competence, terminology system.

Вступ / Introduction. Постіндустріальне суспільство традиційно називають суспільством знань, що свідчить про зміну акцентів у системі суспільного виробництва, суспільних цінностей i суспільних пріоритетів, оскільки основним ресурсом i, водночас, здобутком соціумі нині е знання у якнайширшому глобалізованому сенсі цього поняття. I масштабність поняття, і те, наскільки воно закорінене у всі, без винятку, суспільні процеси, і те, зусиль скількох професійних спільнот воно потребуе, і те, що й сам об'ект освітньої дії як фрілософрська категорія нині суттево змінився, порівняно з попередніми історичними періодами, ускладнюе цю необхідну трансформацію $\mathrm{i}$ розбивае її на кілька етапів і рівнів.

Сучасна система активного, мобільного, глибоко індивідуального й особистісно-орієнтованого інформаційного освітнього континууму потребуе принципово інших, порівняно із попередніми освітніми системами, доктрин, концепцій і практик. Причому ця різниця прикметна для всіх, без винятку, учасників, елементів цього суспільно важливого процесу і способу взаємозв'язку між ними, i, що принципово важливо, першочергово потребуе загального суспільного розуміння значимості освіти як перманентного циклічного процесу формування «людини як особистості та найвищої цінності суспільства» (Про освіту..., 2017). Із цих позицій також принциповим $\epsilon$ розуміння природи освіти, власне й пріоритетно, як перманентного суспільного явища, відтак освіту апріорі слід розглядати як процес неперервний чи з позицій загально суспільних, чи 3 позицій особистісного розвитку. У цьому сенсі вкрай нагальною е потреба формування цілісної системи безперервної освіти.

Мета та завдання / Aim and Tasks. Мета дослідження - аргументувати й довести потребу формування цілісної парадигми системи безперервної освіти, висвітлити її роль у загальному освітньому дискурсі, у загальних рисах окреслити окремі складові досвіду їі запровадження, відтак, синтезувати, систематизувати й представити ключові проблемні питання, що корелюють із основними тенденціями й напрями розвитку безперервної освіти, вирішення яких, власне, забезпечить становлення цілісної парадигми.

Методи / Methods. Для досягнення поставленої мети було використано комплекс адекватних методів дослідження - аналіз, синтез, узагальнення результатів запровадження окремих елементів, проблемних питань і тенденцій розвитку системи безперервної освіти.

Результати / Results. Для сучасного світового освітнього дискурсу характерна низка терміносполук, які чітко відображають пріоритетні процеси розвитку ціеї галузі, а саме: «continuing education» (освіта, яка триває) i «lifelong learning» (навчання впродовж життя»), а також чіткий намір більшості країн світу саме ці освітні стратегії позиціонувати як основні. Такий стан речей зумовлений низкою об'ективних факторів, притаманних більшості сучасних освітніх систем, що відображають ті суспільні процеси, які впливають на освіту як одну зі сфер соціальної політики держави. По-перше, загально визнаний факт - вкрай малий термін придатності компетенцій, здобутих у час навчання. У США навіть запроваджена спеціальна «одиниця виміру старіння знань фахівця - період «напіврозпаду» компетентності, тобто зниження її на 50 \%» (Холодний Г. О., 2015). Зважаючи на стрімкий розвиток науки й виробництва, для багатьох спеціальностей цей момент настає через 5 i менше років, тобто фахівець щойно отримавши диплом, має уже потребу модернізувати свої знання. По-друге, для сучасного світу професій характерне таке явище як «поліпрофесіоналізм» (Холодний Г. О., 2015), тобто успішна професійна соціалізація нині не може бути чітко асоційована із однією спеціальністю (монопрофесіоналізмом (Холодний Г. О., 2015). Відтак, у багатьох країнах світу на вирішення цих завдань прийнято стратегічні рішення, наприклад, «у Німеччині основним гаслом освіти проголошено «Вчитися впродовж всього життя. Вчитися, щоб бути» (Холодний Г. О., 2015). Людство увійшло у фазу незворотних суспільних 
процесів, серед яких - кардинальна зміна на ринку професій і праці, доповнена віртуальна реальність, штучний інтелект. У такому суспільстві людині доведеться співіснувати, співпрацювати, подекуди конкурувати із автоматизованими системами. За підрахунками соціологів «2030 року роботу втратять 400 млн осіб, 375 млн будуть змушені отримувати нові навички» (Рибчинський М., 2019). Отже, единий спосіб залишатись конкурентоспроможним навчатись упродовж життя, тобто безперервна освіта - нагальна вимога часу і соціуму до будьякого працівника. Про важливість і глобальність масштабів проблеми безперервного навчання, як вимоги сучасного світу професій, свідчить також рівень законодавчого забезпечення її вирішення. Показовим слід вважати нормативний документ загальноевропейського значення - Меморандум про безперервну освіту Комісії Європейського Союзу від 30 жовтня 2000 p. (A Memorandum on Lifelong Learning,), що містить, зокрема, шість визначальних принципів і напрямів, пріоритетних для формування новітньої системи безперервної освіти: «1) нові базові знання і навички для всіх; 2) збільшення інвестицій в розвиток людських ресурсів; 3) інноваційні методики навчання i вивчення; 4) нова система оцінки отриманої освіти; 5) розвиток наставництва і консультування; 6) наближення освіти до місця проживання» (A Memorandum on Lifelong... ), а також нормативні документи, прийняті в Україні (Стратегія реформування вищої..., 2015; Стратегія розвитку вищої..., 2020).

Третя важлива характеристика сучасних освітніх стратегій - глобалізаційні процеси світового масштабу. Для новітньої соціальної професійної парадигми важлива мобільність фахівця, його потенційна можливість працевлаштуватись у межах різних соціумів, різних держав, наддержавних професійних спільнот і об’еднань. 3 цією метою створено широкі можливості для академічної мобільності студентів і викладачів через різноманітні програми, наприклад, у Свропі актуальними е «ERASMUS (European Community Action Scheme For The Mobility Of University Students), програми «КОМЕТТ» (обмін інформацією, професорсько-викладацьким складом i студентами), «Leonardo da Vinci» (освіта під час відпустки), «Grundtvig» (система практичного навчання) та ін.» (Холодний Г. О., 2015). Така світова інтеграція освітніх систем свідчить про пріоритет для більшості сфер діяльності інформаційної складової і суспільства знань, тому сучасний етап розвитку безперервної освіти на загально европейському рівні фахівці позиціонують як «верифікаційний» (Заярна В. С., (2015), для якого характерна тенденція позиціонувати «нематеріальні корпоративні активи як інтелектуальний капітал» (Холодний Г. О., 2015).

Наступна, четверта, засаднича характеристика сучасної системи освіти, яка виводить саме безперервне навчання на перше місце у загальній освітній іерархії, - пріоритет у всіх сфрерах виробництва новітніх інформаційних технологій, які вирізняються широкими масштабами та вкрай динамічним розвиток, що, відповідно, потребуе постійної модернізації. Відтак успішними освітніми трендами перших десятиліть XXI ст. стають форми інтерактивного, дистанційного навчання (IMS (Instructional Management System - Система освітнього менеджменту); ARIADNE (Alliance of Remote Instructional Authoring and Distribution Networks for Europe - Альянс по розробці й поширенню освітніх мереж для Свропи); GESTALT (Getting Educational Systems Talking Across Leading-Edge Technologies - впровадження передових технологій в освітні мережі)» (Холодний Г. О., 2015), що засноване саме на новітніх інформаційних технологіях і мае низку суттевих переваг, порівняно із традиційними формами й методами. Сучасні інформаційні технології стають дієвим засобом інтелектуалізації суспільства, й у цьому - їх основне завдання у контексті суспільного прогресу.

П'ята підстава для пріоритету безперервної освіти, - запровадження як пріоритетного компетентнісного підходу. Динамізм виробництва продуктів і послуг, інтелектуальної сфери формують динамічну систему компентностей. Відповідно до Національної рамки кваліфікацій (затверджена Постановою Кабінету Міністрів України № 1341 від 23.11.2011р.), компетентність «здатність особи до виконання певного виду діяльності, що виражається через знання, розуміння, уміння, цінності, інші особисті якості» (Про затвердження Національної..., 2011). Закон України «Про освіту» подае таке визначення «компетентність - динамічна комбінація знань, умінь, навичок, способів мислення, поглядів, цінностей, інших особистих якостей, що визначає здатність особи успішно соціалізуватися, провадити професійну та/або подальшу навчальну діяльність» (Про освіту..., 2017). Енциклопедія освіти пропонуе таку дефініцію: «професійна компетентність (лат. professio - oфiцiйно оголошене заняття; compete - досягати, відповідати, підходити) інтегративна характеристика ділових і особистісних якостей фахівця, що відображає рівень знань, умінь, досвіду, достатніх для досягнення мети з певного виду професійної діяльності, а також моральну позицію фахівця» (Енциклопедія освіти, 2008).

Із моменту, коли у другій половині XX століття безперервну освіту (Lifelong Education) як науковий феномен науково обгрунтував Поль Ленгранд у дослідженні «An Introduction to Lifelong Education (UNESCO, Paris, 1970, 99 р.), і сам термін, і явище, ним окреслене, суттево змінилися. Як 
і будь-який науковий феномен, що розвивається емпірично, ця система видозмінювалася, виконуючи конкретні суспільні завдання у певний історичний період. Нині відповідна проблематика характерна для освітніх систем усіх сфер виробництва та інтелектуальної діяльності загалом. Загальними е також і ті проблемні питання, що виникли як реакція на сучасні вимоги до новітніх освітніх продуктів і послуг у сфері безперервної освіти, які сформульовано на основі аналізу практичної діяльності, спрямованої на формування системи безперервної освіти, та документного потоку відповідної тематики. Вирішення цих проблемних питань дозволить сформувати цілісну парадигму системи безперервної освіти. Із-поміж них визначальними є такі:

I. Необхідність нормування терміносистеми безперервної освіти від найпростішого усталення на рівні окремих терміносполук та їх термінологічного поля аж до формування загальної теоретико-практичної парадигми. Наявність і стан розвитку терміносистеми будь-якої галузі, безперечно, e ознакою певного рівня ії розвитку, а також

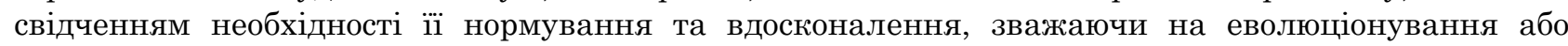
видозміну самого явища як такого. Саме такою показовою е ситуація із терміносистемою у царині безперервної освіти. По-перше, використовуваний термінологічний ряд - «безперервна освіта», «післядипломна освіта», «самоосвіта», «освіта для сталого розвитку», «продовжена освіта», «перманентна освіта», «поновлювана освіта», «рекурентна освіта», «освіта впродовж життя», «безперервний професійний розвиток», «освіта дорослих», “самокероване навчання» (Сало А. В., Безперервна освіта...) - відображае, з одного боку, складну філософію означуваного явища, а 3 іншого, відсутність единої позиції у розумінні його характеристик, суспільних завдань тощо. Термінологічний диспут тривае й нині. Про швидку еволюцію цього поняття свідчить бодай такий факт, що у світовій науковій парадигмі цього явища існують паралельно такі терміносполуки як «навчання протягом життя» (lifelong learning) та «навчання шириною в життя» (lifewide learning)» (Карпенко М., 2010), тобто йдеться уже не лише про тривалість освітньої діяльності, а й про її масштаби в конкретний період життя. По-друге, навіть щодо часу й еволющії цього явища немає одностайності серед сучасних дослідників, натомість одностайність спостерігаемо у необхідності активного використання й запровадження усіх форм і методів безперервного навчання як суспільно значущого феномена. 3-поміж інших вирізняеться, зокрема, така дефініція безперервної освіти: «особливий тип освіти, який базуеться на індивідуальній ініціативі до максимального розвитку інтелектуального потенціалу фахівця, через систему навчальних закладів, приватних послуг, Інтернет - технологій, відповідно до потреб власного та професійного розвитку, спрямований на постійне оновлення професійних знань з метою підвищення рівня професійної компетентності» (Сало А. В. Безперервна освіта...).

II. Формування суспільної візії безперервної освіти (принципів, завдань, структури, форм і методів неперервного процесу формування профрільних компетентностей, а основне забезпечення успішної професійної соціалізації особистості, що, власне, й є основним завданням освіти тощо). Дискусії про принципи, ієрархію, рівні, форми, безперевної освіти - невід'ємна складова й етап у формуванні загально-державної освітньої стратегії для суспільства, яке системно розвивається через, зокрема, професійний розвиток кожної окремої особистості. Визначальними засадами, що лежать в основі формування стратегії безперервної освіти прийнято вважати:

1) поступальний розвиток особистості методом вдосконалення первісних знань і відповідних компетентностей через систематичне оновлення професійних якостей, використання новітніх технологій і методів навчання;

2) особистісно орієнтовану траєкторію навчання та самонавчання як спланований процес із певною циклічністю через створення індивідуальних модулів, інтегрованих у загальний освітній процес конкретної галузі, в основі якої критичне системне мислення та позиціонування фрахівця у професійній спільноті;

3) багаторівневий менеджмент і організаційний супровід безперервного навчання через формування навчально-виробничих систем і комплексів на рівні державної освітньої політики як реалізація доктрини менеджменту знань;

4) формування вищої освіти не як стало-завершеної замкнутої системи, а як першого, фундаментального рівня для формування системи освіти впродовж життя, орієнтованого на «поліпрофесіоналізм» (Холодний Г. О., 2015) як ознаку сучасного динамічного суспільнопрофесійного середовища;

5) предметно-модульне кластерне навчання орієнтоване на систему професійних завдань та обов'язків, засноване на використанні новітніх інформаційно-інтелектуальних технологій із огляду на вимоги інтернаціоналізації освіти.

У структурі загальної освіти, що розвиваеться на основі принципів «едності і наступності системи освіти, безперервності і різноманітності освіти» (Про освіту..., 2017), безперервна освіта розвиваеться за принципами «гуманізму демократизму, мобільності, випередження, відкритості» 
(Половая Н. О., 2018).

Попри важливість усіх анонсованих принципів, особливо актуальним нині $е$ принцип індивідуальної траєкторії безперервного навчання, реалізований у варіативності освітньої стратегії i відповідної тактики окремої особистості, як дієвий спосіб розвитку soft skills (Що таке Soft Skills...). Так звані «м'які навички» - система універсальних надпрофесійних управлінських, комунікативних, соціальних навичок, що у сучасній професійній парадигмі, яка е надзвичайно мобільною, порівняно із попередніми періодами суспільного розвитку, має вагоме значення для успішної професійної соціалізації, оскільки передбачае формування у фахівця такої необхідної риси, що корелюе із швидко змінюваним ринком праці, як мобільність і вміння переорієнтуватись у професійному середовищі. Отже, один із пріоритетів безперервного навчання - навчитися вчитися, а також засвоїти основу кризового менеджменту, з позицій якого будь-яка криза не фінал професійної діяльності, а початок іï модернізації в іншій професійній системі координат. Наступний щабель - генерувати власні оригінальні ідеї і завдання для професійного розвитку незаперечна перевага людини, порівняно із машинами, досяжне i обов'язкове завдання безперервної освіти. Для системи безперервної освіти принципово важливим є такий соціальнопедагогічний працівник як коуч i, відповідно, такий процес як коучинг - популярний нині суспільний феномен загально соціального характеру, заснований на особливостях когнітивної психології.

Для формування іерархії безперервної освіти науковці пропонують розрізняти «дві підсистеми - основну і додаткову освіту... основна і додаткова освіта може бути загальною і професійною. Отже, виходить чотири підсистеми освіти: основна загальна, основна професійна, додаткова загальна, додаткова професійна" (Половая Н. О., 2018), а також такі види безперервної освіти «формальне навчання, неформальне навчання, позаформальне навчання» (Половая Н. О., 2018), сформульовані у Меморандумі про безперервну освіту Комісії Свропейського Союзу. Система безперервної освіти виконуе такі суспільно важливі функції: «розвиваюча (задоволення духовних запитів особистості, потреб творчого зростання); компенсуюча (заповнення пробілів у базовій освіті); адаптивна (оперативна підготовка й перепідготовка в умовах мінливої виробничої й соціальної ситуації); інтегруюча в незнайомий культурний контекст; функція ресоціалізації (повторної соціалізації)» (Карпенко М., 2010).

Закономірно, що для безперервної освіти, як системи, що е тривалою у часі, потребуе особливої спеціальної уваги щодо учнівської аудиторії, передбачае якнайширше коло залученого навчального матеріалу, особливо актуальними $е$ нині питання використовуваних методів $\mathrm{i}$ загальних методик навчання, причому і загального характеру, і спеціальних, орієнтованих на конкретне професійне середовище, що має на меті компенсувати систему тих компетентностей, які є найбільш актуальними, натомість не були сформовані попередніми навчальними практиками. Особливо значення у цьому контексті набуває «впровадження інноваційних, інформаційнокомунікативних форм і технологій навчання; у тому числі комп'ютерних тренажерів, віртуальних лабораторій, технологій для модульних програм навчання тощо» (Холодний Г. О., 2015), які $е$ новітніми і за змістом, i, що важливо для фахівців більшості сучасного світу професій, за формою. Способи й методи запровадження безперервної освіти різноманітні, й більшість сучасних державних освітніх ініціатив, передбачають, як правило, й таку складову, реалізовану завдяки найновішим формам і методикам. Одним із способів запровадження безперервної освіти є також Концепція впровадження медіа-освіти, яка «передбачає реалізацію експериментального етапу, поступового укорінення медіа-освіти та стандартизацію вимог до медіа-освіти, і подальший розвиток медіа-освіти та завершення масового запровадження» (Концепція впровадження медіаосвіти...). Серед пріоритетів безперервної освіти - використання колективних форм навчання, де колективна пізнавальна діяльність - шлях до формування оптимальної структури професійно мотивовано колективу з чітким розподілом функціональних обов'язків, відповідно до оптимального використання особистості у колективній професійній діяльності. Управління персоналом, бізнескомунікація - атрибути безперервної освіти незалежно від галузі.

Усі ці характеристики слід об'єднати в одне поняття, притаманне для сучасного освітнього концепту - «Культура безперервного навчання» (Рибчинський М., 2019), що е основою «европейської соціальної моделі» (Карпенко М., 2010), орієнтованої на особистісний розвиток упродовж життя. У масштабах державного управління безперервна освіта має стати окремою цариною соціальної політики, і лише таке позиціонування може забезпечити належний рівень розвитку відповідних освітніх стратегій, зрештою глобально безперервну освіту слід розглядати і в ракурсі національної безпеки.

III. Належне нормативно-правове забезпечення функціонування безперервної освіти як цілісної системи на рівні законів і підзаконних актів. Масштабне запровадження концепцій безперервної освіти у світовій освітній практиці перебуває уже на достатньо високому 
рівні розвитку. Про це свідчать численні законодавчі ініціативи у цій галузі, які мають понаддержавний інтеграційний характер, і прийняті країнами Європейського Союзу як спільні стратегічні документи, що формують основу парадигму безперервної освіти, а саме «резолюція Європейського Союзу з питання про безперервну професійну освіту (1989р.), Європейська стратегія зайнятості (1997р.), висновки саміту Свропейського Союзу з питання «про освіту протягом всього життя» (2000р.), Меморандум про безперервну освіту Комісії Європейського Союзу (2000р.)» (Кудрявцева С. П. \& Колос В. В., 2005). «У 2006 році «Європейська Комісія об’еднала різні освітні й навчальні ініціативи в едину Програму навчання протягом життя (Lifelong Learning Programme)» (Карпенко М., 2010).

Окремі галузі практичної діяльності у нашій державі мають уже відповідне законодавче підгрунтя для розвитку безперервної освіти, так із 2019 року в Україні запроваджено програму безперервного професійного розвитку для лікарів (MO3 України впроваджуе..., 2019). Науковці одностайні у тому, що «з метою створення оптимальної структури треба внести зміни в статті 29,47 , 48, 56 Закону України «Про освіту» (Мандрика О. І. Безперервна освіта педагогічного...).

В Україні, попри однозначну позицію теоретиків і практиків інформаційно-бібліотечної галузі щодо доцільності й необхідності вибору саме такої освітньої моделі - навчання впродовж життя, наразі немає цілісної комплексної, затвердженої на рівні держави, програми безперервної освіти фахівців ціеї сфери виробництва інформаційних продуктів і послуг, проте е окремі закони й підзаконні акти, які загалом регламентують таку освітню діяльність. Так, стаття 18 Закону України «Про освіту» «Освіта для дорослих» позиціонуе цю сферу як частину стратегії освіти впродовж життя, а також розрізняе такі складники цього явища: «післядипломна освіта; профресійне навчання працівників; курси перепідготовки та/або підвищення кваліфікації; безперервний професійний розвиток; будь-які інші складники, що передбачені законодавством, запропоновані суб'єктом освітньої діяльності або самостійно визначені особою» (Про освіту..., 2017) та визначення поняття «безперервний професійний розвиток» як безперервний процес навчання та вдосконалення професійних компетентностей фахівців після здобуття вищої та/або післядипломної освіти, що дає змогу фахівцю підтримувати або покращувати стандарти профресійної діяльності i тривае впродовж усього періоду його професійної діяльності» (Про освіту..., 2017). В указі Президента України «Про Національну доктрину розвитку освіти» є окремий підрозділ, що містить вісім програмних засад, які регламентують освітню діяльність у сфері безперервної освіти i навчання протягом життя (Про Національну доктрину..., 2002).

IV. Формування у системі державного управління інфраструктури із профільних інституцій та організацій, здатних створювати належні освітні продукти й надавати відповідні освітні послуги у рамках безперервної освіти. На вимогу суспільного запиту безперервної освіти більшості галузей сучасні заклади освіти тяжіють до науково-виробничих осередків, завдання яких - налагодити організаційні й технічні аспекти сучасної освітньої індустрії, зважаючи на соціально-психологічні особливості учнівської аудиторії 3 огляду на суспільний резонанс професійної соціалізації впродовж життя. Для цього процесу характерні «диверсифікації та інтернаціоналізації освіти» (Холодний Г. О., 2015). Глобальність масштабів проблеми вимагае рішень відповідного рівня, тому це питання соціального розвитку не окремої держави, а усього суспільного розвитку. Так само, як свого часу індустріальна революція змінила нашу цивілізацію, інформаційна революція створила нову реальність, у якій професія змінювана, а не константа. Вирішення цих глобальних питань потребуе загальної реформи усієї освітньої інфраструктури і створення навчальних закладів нового типу «учбово-консультаційних комплексів - нової організаційної структури, що дозволяе реалізувати поставлені цілі через об’єднання потенціалу вищих навчальних закладів і конкретних підприємств» (Холодний Г. О., 2015). Успіх такої інтеграції - у самій природі двох компонентів: навчальний заклад забезпечуе навчальну (освітні програми, кадровий склад, методичні ресурси) й науково-дослідну складову, виробництво, вирішуючи щоденні практичні завдання, формуе коло новітніх фрахових компетентностей. Ця практика уже успішно апробована на рівні залучення стейкхолдерів до формування освітніх програм закладів освіти, моніторингу професійної соціалізації, залучення фахівців-практиків до читання лекційних курсів, апробації семінарів, практик тощо. У межах держави чи групи держав такі структури утворюють особистісно оріентований освітній конгломерат, обов'язкова частина якого - «інформаційно-комунікаційний освітній простір, віртуальне середовище, що включае безліч освітніх ресурсів для підтримки навчальної діяльності і рішення задачі навчання на базі глобальних комп'ютерних комунікацій» (Кудрявцева С. П. \& Колос В. В., 2005). На часі також організація «корпоративних університетів, що забезпечують чергування одержання фундаментальних знань із практичною діяльністю» (Карпенко М., 2010).

V. Масштабне залучення сучасних інформаційних технологій електронного
навчання (Electronic learning)


інноваційних методик викладання. Система фрахових компетентностей сучасного працівника традиційно передбачає активне використання сучасних інформаційних технологій, незалежно від сфери виробництва. Подекуди успіх професійної діяльності напряму залежить від уміння функціональні завдання професійної практики вирішувати через використання цілої системи Інформаційних технологій. 3 огляду на це, для формування системи новітніх професійних компетентностей вкрай необхідними е новітні засоби й способи організації освітнього процесу 3 використанням, власне, IT, а саме «комп'ютерні навчальні програми (наприклад, веб-квести проблемні завдання 3 елементами рольової гри, для виконання якої використовуються інформаційні ресурси Інтернет); навчальні системи на базі мультимедіа-технологій; інтелектуальні та навчальні експертні системи; $\square$ розподілені бази даних; засоби телекомунікації, програмні та технічні засоби IT; віртуальні електронні бібліотеки; розподілені та централізовані видавничі системи; передача знань на мобільний пристрій з використанням WAP або GPRS технологій - Mobile» (Холодний Г. О., 2015). У сучасному освітньому просторі набувають обертів освітні онлайн-платформи і маркетплейси, пік використання яких припаде на період зміни у професійній діяльності покоління Millennials поколінням $\mathrm{Z}$, яке уже зараз обирає пріоритетними дистанційні форми навчання, що, відповідно, буде актуальним і для його безперервної освіти.

Обговорення / Discussions. Безперервна освіта як суспільне явище й певний рівень загального освітнього процесу, чи, радше, окремі ії елементи, виникли значно раніше, аніж виникло це поняття і відповідні його дефініції. Знаковою подією для розвитку загального концепту i науково-практичного вчення зокрема мала конференція, проведена під егідою організації світового масштабу - ЮНЕСКО 1965 р. та доповідь комісії під керівництвом Е. Фора «Вчитися, щоб бути». Розвиток цього концепту, чи окремих його елементів обчислюемо не одним століттям, про що, зрештою, свідчать численні масштабні дослідження (основу наукових досліджень цієї сфери заклали Г. Беккер, Д. Белл, П. Друкер, Р. Даве, Х. Гуммель, П. Ленгранд, Г. Коптаж, Е. Тофорлер, Е. Фор, М. Вачевський, Р. Гуревич, Н. Дем'яненко, Т. Десятов, М. Згуровський, В. Кремень, В. Лозовецька, І. Лікарчук, Н. Ничкало, С. Сисоева, Г. Філіпчук (Холодний Г. О., 2015) та відповідна сучасна історіографрія цього питання, представлена роботами науковців різних царин від загальних педагогів до фахівців окремих спеціальностей і галузей знань (Бабич М. С., 2015; Везетіу К. В.Безперервна освіта як універсальний...; Гагарін О. О., 2007; Давидов П., 2015; Загородня Л., 2016; Заярна В. С., 2015; Карпенко М., 2010; Концепція впровадження медіаосвіти..., 2016; Коренева I. М., 2018; Кристопчук Т. Є., 2017; Мамедова I., 2013; Мандрика О. I. Безперервна освіта педагогічного...; Неперервна освіта для сталого розвитку...; Половая Н. О., 2018; Рибчинський М., 2019; Салата Г. В., 2017; Сало А. В. Безперервна освіта як пріоритетний...; Топчий Т. В., 2014). У численних дослідженнях безперервної освіти науковці обгрунтували еволюцію терміну, періодизацію розвитку безперервної освіти, шляхи реалізації відповідних освітніх практик (Бабич М. С., 2015) тощо. Попри значну увагу до безперервної освіти як «комплексу державних, приватних і суспільних освітніх установ, що забезпечують організаційну i змістовну єдність і подальший взаємозв'язок всіх ланок освіти, задовольняючи прагнення людини до самоосвіти i розвитку протягом всього життя» (Кудрявцева С. П. \& Колос В. В., 2005), розгалужені й політематичні дослідження ціеї проблеми кількох попередніх десятиліть, «вітчизняні учені, досліджуючи втілення ідеї безперервної освіти у реальному житті, дійшли висновку, що цілісна концепція безперервної освіти поки що відсутня» (Бабич М. С., 2015). Принципова позиція також полягае у тому, що модернізувати освітню стратегію розрізненими, хаотичними ініціативами неможливо, слід створити новітню цілісну систему безперервної освіти (сталого розвитку у продовж життя).

Знакова подія для розвитку безперервної освіти в Україні відбулася 7 вересня 2020 р., коли Міністерство освіти і науки України запропонувало для громадського обговорення Законопроєкт про освіту для дорослих (6 розділів, 31 стаття) (Законопроект про освіту дорослих..., 2020). Ця ініціатива виключно важлива, оскільки дозволить унормувати відповідну професійну діяльність, належне фінансування галузі, інтегрування України у світовий освітній простір. Також важливо, що у термінологічному полі на законодавчому рівні зафіксовані терміни й поняття «андрагог», «провайдер освіти дорослих», «Національна рада з питань освіти дорослих» тощо. У законопроекті також розширено коло складників освіти дорослих. Автори документа пропонують п'ять типів програм, за якими будуть надавати освіту дорослим. У документі спеціально передбачено механізми заохочення освітніх ініціатив і для працівників, і для працедавців (Законопроект про освіту дорослих..., 2020).

Висновки / Conclusions. Отже, в умовах сучасного постіндустріального суспільства знань система освітніх продуктів і послуг зазнае глобальних змін, зумовлених тектонічними змінами у загальній філософіï суспільного буття. Модернізація освіти - стратегічне завдання сучасного соціуму й, водночас, передумова й запорука його динамічного розвитку. Безперервна освіта - 
едукаційна домінанта, що виникла як відповідь на професійні запити цього суспільства, в основі яких - запроваджений на початку XXI століття компетентісний підхід. Як основна інвестиція для успішної професійної соціалізації працівника у XXI столітті безперервна освіта потребуе системних стратегічних підходів і рішень задля формування єдиної цілісної освітньої парадигми.

\section{Список використаних джерел і літератури:}

Про затвердження Національної ралки кваліфбікацій № 1341. (2011). Взято з http://zakon4.rada.gov.ua/laws/show/1341-2011-\%D0\%BF [in Ukrainian].

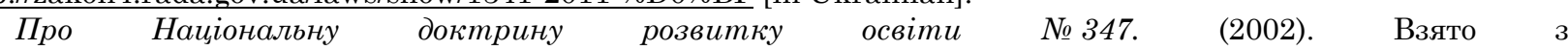
https://zakon.rada.gov.ua/laws/show/347/2002\#Text [in Ukrainian].

Про освіту № 2145-VIII від 5 вересня 2017 року Взято 3 https://zakon.rada.gov.ua/laws/show/2145-19 [in Ukrainian].

Законопроект про освіту дорослих: основні положення. Взято з https://osvita.ua/vnz/76707/ [in Ukrainian].

Бабич, М. С. (2015). Безперервна освіта (освіта впродовж життя) - умова підвищення національної конкурентоспроможності. Вісник Хмельницького національного університету. Еконолічні науки, 5, 50-53 [in Ukrainian].

Безперервна освіта - один із трендів 2019 року (2019). Взято 3 https://blog.uamaster.com/corporateeducation-as-trend/ [in Ukrainian].

Бондар, М. (2020). Законопроєкт про освіту для дорослих: основні положення та деталі. Взято з https://education.24tv.ua/zakonoproyekt-pro-osvitu-doroslih-polozhennya-novini-ukrayini_n1420423 Ukrainian].

Везетіу, К. В. (б.д.). Безперервна освіта як універсальний засіб здійснення процесу освіти. Взято з http://intkonf.org/vezetiu-kv-bezperervna-osvita-yak-universalniy-zasib-zdiysnennya-protsesu-osviti/ Ukrainian].

Гагарін, О. О. (2007). Дослідження і аналіз методів та моделей інтелектуальних систем безперервного навчання. Наукові вісті Національного технічного університету Украӥни "Київський політехнічний iнститут", 6, 37-48 [in Ukrainian].

Давидов, П. (2015). Безперевність освіти - виклик сучасності Особистість, суспільство, політика 2015: матеріали II міжнар. наук.-практ. конф. (с. 14-17). Люблін [in Ukrainian].

Енциклопедія освіти. (2008). (Ред. В. Г. Кремень). Київ: ЮрінкомІнтер [in Ukrainian].

Загородня, Л. (2016). Безперервна бібліотечна освіта як важливий чинник розвитку бібліотечної професії: історія та сьогодення Наукові праці Національної бібліотеки Украӥни ілені В. I. Вернадського, 44, 171-190. Взято з http://nbuv.gov.ua/UJRN/npnbuimviv_2016_44_17 [in Ukrainian].

Заярна, В. С. (2015). Етапи розвитку міжнародного співробітництва у сфері неформальної освіти в Свропейському Союзі. Педагогіка фборлування творчої особистості у вищій $i$ загальноосвітній школах, 45, 94-102 [in Ukrainian].

Карпенко, М. (2010). Освіта протягол життя: світовий досвід і украӥнська практика: аналітична записка. Взято 3 https://niss.gov.ua/doslidzhennya/gumanitarniy-rozvitok/osvita-protyagom-zhittya-svitoviydosvid-i-ukrainska-praktika [in Ukrainian].

Концепиія впровадження медіа-освіти в Україні $_{\text {(нова редакиія) }}$ Взято 3 https://ms.detector.media/mediaosvita/post/16501/2016-04-27-kontseptsiya-vprovadzhennya-mediaosvity-v-ukraininova-redaktsiya/ [in Ukrainian].

Коренева, I. М. (2018). Феномен «Освіта для сталого розвитку»: сутність та сучасні особливості концепту. Украӥнський педагогічний журнал, 2, 113-123 [in Ukrainian].

Кристопчук, Т. С. (2017.) Законодавче регулювання та особливості видів освітньої діяльності у контексті неперервної освіти у европейських країнах. Молодий вчений, 5, 62-65 [in Ukrainian].

Кудрявцева, С. П., \& Колос, В. В. (2005). Міжнародна інфорлація. Київ: Видавничий Дім «Слово». Взято 3 https://buklib.net/books/24166/ [in Ukrainian].

Кунанець, Н. Е. (2013). Інфбормаційно-бібліотечне обслуговування користувачів з особливили потребали: історія та сучасність. Львів: Галищька видавнича спілка [in Ukrainian].

Мамедова, I. (2013). Ефективність безперервної освіти, освіта продовж усього життя. Молодь $i$ ринок, 9 , 144-148 [in Ukrainian].

Мандрика, О. І. Безперервна освіта педагогічного колективу за систелою індивідуальних траєкторій. Взято з https://virtkafedra.ucoz.ua/el_gurnal/pages/vyp8/Mandrik.pdf [in Ukrainian].

МОЗ Украӥни впроваджує систелу безперервного проббесійного розвитку (БПР) для лікарів. (2019). Взято 3 https://moz.gov.ua/article/reform-plan/moz-ukraini-vprovadzhue-sistemu-bezperervnogo-profesijnogorozvitku-bpr-dlja-likariv [in Ukrainian].

МОН пропонує для громадського обговорення законопроєкт "Про освіту дорослих». (2020). Взято 3 https://mon.gov.ua/ua/news/mon-proponuye-dlya-gromadskogo-obgovorennya-zakonoproyekt-pro-osvitu-doroslih [in Ukrainian].

Неперервна освіта для сталого розвитку: фбілособбсько-теоретичні контексти та педагогічна практика: матеріали II всеукр. наук.-практ. конф. Дніпро: СПД «Охотнік» [in Ukrainian].

Половая, Н. О. (2018). Безперервна освіта як вектор розвитку інформаційного суспільства. Грані, 4, 9196. Взято зhttp://nbuv.gov.ua/UJRN/Grani_2018_21_4_15 [in Ukrainian].

Рибчинський, М. (2019). Безперервна освіта - ключовий тренд майбутнього. Взято з 
https://www.epravda.com.ua/columns/2019/11/29/654273/ [in Ukrainian].

Салата, Г. В. (2017). Безперервна бібліотечно-інформаційна освіта в сучасних умовах соціальноекономічного розвитку України: нотатки до проблеми, Сучасна інборлаційно-бібліотечна освіта: європейські орієнтири: матеріали VII міжнар. наук.-практ. конф. (с. 25-30). Київ: УБА [in Ukrainian].

Сало, А. В. Безперервна освіта як пріоритетний напрялок підвищення профбесійної колпетентності gбахівиів. Взято з http://www.economy.nayka.com.ua/?op=1\&z=5505 [in Ukrainian].

Стратегія реформування вищої освіти в Україні до 2020 року. Взято 3 http://mdu.edu.ua/wpcontent/uploads/2015/01/strategiya_reformuvannya_vyshchoyi_osvity_2.0.pdf [in Ukrainian].

Стратегія розвитку вищої освіти в https://mon.gov.ua/storage/app/media/rizne/2020/09/25/rozvitku-vishchoi-osviti-v-ukraini-02-10-2020.pdf [in Ukrainian].

Топчий, Т. В. (2014). Безперервна освіта як системне середовище формування особистості. Вісник Національного університету “Юридична академія України ілені Ярослава Мудрого, 3, $222-228$ [in Ukrainian].

Холодний, Г. О. (2015). Особливості та перспективи безперервної освіти в системі кадрового забезпечення маркетингової діяльності підприемств. Проблели еконоліки, 2, 194-200[in Ukrainian].

Що таке Soft Skills $i$ для чого $\ddot{x}$ треба розвивати. Взято 3 https://www.work.ua/articles/selfdevelopment/2049/ [in Ukrainian].

European Communities: A Memorandum on Lifelong Learning, issued in 2000. Retrieved from https://uil.unesco.org/document/european-communities-memorandum-lifelong-learning-issued-2000 [in English].

\section{References:}

Pro zatverdzhennia Natsionalnoi ramky kvalifikatsii [On Approval of the National Qualifications Framework № 1341]. (2011). Retrieved from http://zakon4.rada.gov.ua/laws/show/1341-2011-\%D0\%BF [in Ukrainian].

Pro Natsionalnu doktrynu rozvytku osvity [On the National Doctrine of Education Development]. (2002). Retrieved from https://zakon.rada.gov.ua/laws/show/347/2002\#Text [in Ukrainian].
Pro
osvitu № 2145-VIII
$05.09 .2017 \quad[\mathrm{On}$
Education].
(2017).
Retrieved
from

https://zakon.rada.gov.ua/laws/show/2145-19 [in Ukrainian].

Zakonoproekt pro osvitudoroslykh: osnovnipolozhennia [Legislative Draft on Adult Education: Basic Provisions]. Retrieved from https://osvita.ua/vnz/76707/ [in Ukrainian].

Babych, M. S. (2015). Bezperervna osvita (osvita vprodovzh zhyttia) - umova pidvyshchennia natsionalnoi konkurentospromozhnosti [Lifelong Education (Life long Learning) as a Required Condition for National Competitiveness Increase]. Visnyk Khmelnytskoho natsionalnoho universytetu. Ekonomichni nauky - Bulletin of Khmelnytsky National University. Economic Sciences, 5, 50-53 [in Ukrainian].

Bezperervnaosvita - odyn iz trendiv 2019 roku [Continuing Education is One of the 2019 Trends]. (2019). Retrieved from https://blog.uamaster.com/corporate-education-as-trend/ [in Ukrainian].

Bondar, M. (2020). Zakonoproiekt pro osvitu dlia doroslykh: osnovni polozhennia ta detali [Legislative Draft on Adult Education: Basic Provisions and Details]. Retrieved from https://education.24tv.ua/zakonoproyekt-proosvitu-doroslih-polozhennya-novini-ukrayini_n1420423 [in Ukrainian].

Vezetiu, K. V. Bezperervna osvita yak universalnyi zasib zdiisnennia protsesu osvity [Continuing Education as a Universal Means of Implementing the Education Process]. Retrieved from http://intkonf.org/vezetiu-kvbezperervna-osvita-yak-universalniy-zasib-zdiysnennya-protsesu-osviti/ [in Ukrainian].

Haharin, O. O. (2007). Doslidzhennia i analiz metodiv ta modelei intelektualnykh system bezperervnoho navchannia [Research and Analysis of Methods and Models for Intelligent Systems of Continuing Education] Naukovi visti Natsionalnoho Tekhnichnoho Universytetu Ukrainy "Kyivskyi Politekhnichnyi Instytut» - Buletin of the National Technical University of Ukraine "Kyiv Polytechnic Institute», 6, 37-48 [in Ukrainian].

Davydov, P. (2015). Bezperevnist osvity - vyklyk suchasnosti [Continuity of Education as a Modern Challenge] Osobystist, suspilstvo, polityka - 2015: Proceedings of the II International Scientific and Practical Conference (pp. 14-17). Liublin [in Ukrainian].

Entsyklopediia osvity [Encyclopedia of Education]. (2008). (Ed. V. H. Kremen). Kyiv: YurinkomInter [in Ukrainian].

Zahorodnia, L. (2016). Bezperervna bibliotechna osvita yak vazhlyvyi chynnyk rozvytku bibliotechnoi profesii: istoriia ta sohodennia [Continuing Library Education as an Important Factor in the Development of the Library Profession: History and the Present]. Naukovi pratsi Natsionalnoi biblioteky Ukrainy imeni V. I. Vernadskoho - Scientific Works of the National Library of Ukraine named after V. I. Vernadskyi, 44, 171-190. Retrieved from http://nbuv.gov.ua/UJRN/npnbuimviv_2016_44_17 [in Ukrainian].

Zaiarna, V.S. (2015). Etapy rozvytku mizhnarodnoho spivrobitnytstva u sferi neformalnoi osvity v yevropeiskomu soiuzi [Stages of Development of International Cooperation in the Field of Non-formal Education in the European Union]. Pedahohika formuvannia tvorchoi osobystosti u vyshchii $i$ zahalnoosvitnii shkolakh Pedagogy of Formation of Creative Personality in Higher and Secondary Schools, 45, 94-102 [in Ukrainian].

Karpenko, M. (2010). Osvita protiahom zhyttia: svitovyi dosvid i ukrainska praktyka: analitychna zapyska [Lifelong Education: World Experience and Ukrainian Practice: An Analytical Note]. Retrieved from https://niss.gov.ua/doslidzhennya/gumanitarniy-rozvitok/osvita-protyagom-zhittya-svitoviy-dosvid-i-ukrainskapraktika [in Ukrainian].

Kontseptsiia vprovadzhennia media-osvity $v$ Ukraini (nova redaktsiia) [The Concept of Introducing Media

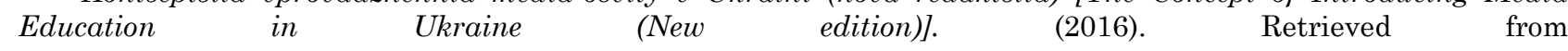


https://ms.detector.media/mediaosvita/post/16501/2016-04-27-kontseptsiya-vprovadzhennya-mediaosvity-v-ukraininova-redaktsiya/ [in Ukrainian].

Koreneva, I. M. (2018). Fenomen «Osvita dlia staloho rozvytku»: sutnist ta suchasni osoblyvosti kontseptu [The Phenomenon of «Education for Sustainable Development»: the Essence and Modern Features of the Concept]. Ukrainskyi pedahohichnyi zhurnal - Ukrainian Pedagogical Journal, 2, 113-123 [in Ukrainian].

Krystopchuk, T. Ye. (2017). Zakonodavche rehuliuvannia ta osoblyvosti vydiv osvitnoi diialnosti u konteksti neperervnoi osvity u yevropeiskykh krainakh [Legislation and Features of Educational Activities in the Context of Continuing Education in European Countries]. Molodyi vchenyi-Young Scientist, 5, 62-65 [in Ukrainian].

Kudriavtseva, S. P., \& Kolos, V. V. (2005). Mizhnarodna informatsiia [International Information]. Kyiv: Vydavnychyi Dim «Slovo». Retrieved from https://buklib.net/books/24166/ [in Ukrainian].

Kunanets, N. E. (2013). Informatsiino-bibliotechne obsluhovuvannia korystuvachiv z osoblyvymy potrebamy: istoriia ta suchasnist [Information and Library Service for Users with Special Needs: History Andnowsadays]. Lviv: Halytska vydavnycha spilka [in Ukrainian].

Mamedova, I. (2013). Efektyvnist bezperervnoi osvity, osvita prodovzh usoho zhyttia [Effectiveness of Continuing Education, Lifelong Education]. Molod i rynok - Youth and Market, 9, 144-148 [in Ukrainian].

Mandryka, O. I. Bezperervna osvita pedahohichnoho kolektyvu za systemoiu indyvidualnykh traiektorii [Continuing Education of the Teaching Staff According to the System of Individual Trajectories]. Retrieved from https://virtkafedra.ucoz.ua/el_gurnal/pages/vyp8/Mandrik.pdf [in Ukrainian].

MOZ Ukrainy vprovadzhuie systemu bezperervnoho profesiinoho rozvytku (BPR) dlia likariv [Ministry of Health of Ukraine Introduces the System of Continuing Professional Development (BPR) for Doctors] (2019). Retrieved from https://moz.gov.ua/article/reform-plan/moz-kraini-vprovadzhue-sistemu-bezperervnogo-profesijnogorozvitku-bpr-dlja-likariv [in Ukrainian].

MON proponuie dlia hromadskoho obhovorennia zakonoproiekt "Pro osvitudoroslykh" [The Ministry of Education and Science Has Suggested Legislative Draft "On Adult Education" for the Community Discussion]. (2020). Retrieved from https://mon.gov.ua/ua/news/mon-proponuye-dlya-gromadskogo-obgovorennyazakonoproyekt-pro-osvitu-doroslih [in Ukrainian].

Neperervna osvita dlia staloho rozvytku: filosofsko-teoretychni konteksty ta pedahohichna praktyka [Continuous Education for Constant Development: Philosophical and Theoretical Contexts and Pedagogical Practice]: Proceedings of the Conference. Dnipro: SPD «Okhotnik» [in Ukrainian].

Polovaia, N. O. (2018). Bezperervna osvita yak vektor rozvytku informatsiinoho suspilstva [Continuing Education as a Vector for Information Society Development]. Hrani, 4, 91-96. Retrieved from http://nbuv.gov.ua/UJRN/Grani_2018_21_4_15 [in Ukrainian].

Rybchynskyi, M. (2019). Bezperervna osvita - kliuchovyi trend maibutnoho [Continuing Education as a Key Trend of the Future]. Retrieved from https://www.epravda.com.ua/columns/2019/11/29/654273/ [in Ukrainian].

Salata, H. V. (2017). Bezperervna bibliotechno-informatsiina osvita $\mathrm{v}$ suchasnykh umovakh sotsialnoekonomichnoho rozvytku Ukrainy: notatky do problemy [Continuing Library and Information Education in Modern Conditions of Socio-Economic Development of Ukraine: Notes to the Problems]. Suchasna informatsiinobibliotechna osvita: yevropeiski oriientyry: Proceedings oft he Conference (pp. 25-30). Kyiv: UBA [in Ukrainian].

Salo, A. V. Bezperervna osvita yak priorytetnyi napriamok pidvyshchennia profesiinoi kompetentnosti fakhivtsiv [Continuing Education as a Priority Area for Improving the Professional Competence of Specialists]. Retrieved from http://www.economy.nayka.com.ua/?op=1\&z=5505 [in Ukrainian].

Stratehiia reformuvannia vyshchoi osvity v Ukraini do 2020 roku [Strategy for Reforming Higher Education in Ukraine till 2020]. (2015). Retrieved from http://mdu.edu.ua/wpcontent/uploads/2015/01/strategiya_reformuvannya_vyshchoyi_osvity_2.0.pdf [in Ukrainian].

Stratehiia rozvytku vyshchoi osvity v Ukraini na 2021-2031 roky [Strategy for Reforming Higher Education in Ukraine for 2021-2031]. (2020). Retrieved https://mon.gov.ua/storage/app/media/rizne/2020/09/25/rozvitku-vishchoiosviti-v-ukraini-02-10-2020.pdff [in Ukrainian].

Topchyi, T. V. (2014). Bezperervna osvita yak systemne seredovyshche formuvannia osobystosti [Continuing Education as a Systemic Environment for the Formation of a Personality]. Visnyk Natsionalnoho universytetu "Yurydychna akademiia Ukrainy imeni Yaroslava Mudroho - Bulletin of the National University "Yaroslav Mudryi Law Academy of Ukraine", 3, 222-228 [in Ukrainian].

Kholodnyi, H. O. (2015). Osoblyvosti ta perspektyvy bezperervnoi osvity v systemi kadrovoho zabezpechennia marketynhovoi diialnosti pidpryiemstv [Features and Prospects of Continuing Education in the System of Staffing of Marketing Activities of Enterprises]. Problemy ekonomiky - Problems of the Economics, 2, 194-200 [in Ukrainian].

Shcho take Soft Skills i dlia choho yikh treba rozvyvaty [What Soft Skills Mean and why They Need to Be Developed]. Retrieved from https://www.work.ua/articles/self-development/2049/ [in Ukrainian].

European Communities: A Memorandum on Lifelong Learning, issued in 2000. Retrieved from https://uil.unesco.org/document/european-communities-memorandum-lifelong-learning-issued-2000 [in English].

Дата надходження статті: «06» жовтня 2020 р.

Стаття прийнята до друку: «11» листопада 2020 р.

Волковецька Романа - магістрант Львівського національного університету імені Івана Франка Volkovetska Romana - Postgraduate Student of Ivan Franko National University of Lviv 
Мудроха Валентина - завідувач відділу бібліотекознавства Львівської національної наукової бібліотеки імені Василя Стефаника, кандидат наук з соціальних комунікацій

Mudrokha Valentyna - Head of the Department of Library Science of Vasyl Stefanyk National Scientific Library of Ukraine in Lviv, Candidate of Sciences in Social Communications

Демчук Наталія - завідувач кафедри бібліотекознавства та бібліографії Львівського національного університету імені Івана Франка, кандидат філологічних наук

Demchuk Nataliia - Head of the Department of Library Science and Bibliography of Ivan Franko National University of Lviv, Candidate of Philological Sciences

Цитуйте цљю статтюяк:

Волковецька, P., Мудроха, В., \& Демчук, H. Volkovetska, R., Mudrokha, V., \& Demchuk, N. (2020). Безперервна освіта як домінанта сучасної освітньої парадигми. Педагогічний дискурс, 29, 5161. doi: 10.31475/ped.dys.2020.29.07.
(2020). Continuing Education as a Dominant Element of the Modern Educational Paradigm. Pedagogical Discourse, 29, 51-61. doi: 10.31475/ped.dys.2020.29.07. 